FACTA UNIVERSITATIS

Series: Teaching, Learning and Teacher Education Vol. 3, № 2, 2019, pp. $109-119$

https://doi.org/10.22190/FUTLTE1902109M

Original research paper

\title{
THE SEVERITY OF PSYCHOSOMATIC PROBLEMS AND PROCRASTINATION IN STUDENTS
}

UDC 159.923:378.18; 159.947.5; 378.18:159.97

\section{Marina Malobabić1, Danijela Živković2, Nebojša Ranđelovićz}

\author{
${ }^{1}$ Neurology Clinic, Clinical Center Niš, Serbia \\ ${ }^{2}$ Faculty of Sport and Physical Education, University of Niš, Serbia
}

\begin{abstract}
The aim of the study was to investigate the correlation between the tendency to manifest psychosomatic reactions and procrastination in students of the Faculty of Sport and Physical Education, as well as to examine the differences in the tendency to manifest psychosomatic symptoms and procrastination in relation to gender and age. The study involved 459 students from the Faculty of Sports and Physical Education in Niš, of which 25 subjects with chronic diseases (asthma, allergies, diabetes, etc.) were excluded from the study. The subjects completed the Psychosomatic Symptoms Scale (PSS) (Vulić-Prtorić, 2005, 2016) and Procrastination Assessment Scale (PASS) Solomon \& Rothblum, 1984. The results showed that there was a statistically significant positive correlation between the tendency to exhibit pseudoneurological, cardiovascular-respiratory, gastrointestinal and pain-musculoskeletal symptoms and procrastination, a statistically significant positive correlation between age and the frequency of pseudoneurological symptoms, as well as a statistically significant correlation between age and procrastination rate. We also found that women were more likely to exhibit psychosomatic problems than men.
\end{abstract}

Key words: psychosomatic symptoms, pseudoneurological symptoms, procrastination.

\section{INTRODUCTION}

Diseases, ie. functional and structural disorders of particular bodily organs and systems whose etiology, in addition to a number of other factors, are crucial factors of a psychological nature, are called psychosomatic disorders and diseases. When we talk about psychosomatic disorders they are referred to as functional alterations to an organ or system, while diseases are discussed when there are disorders of structural nature (Adamović, 1983; Zotović, 2002). The term "psychosomatics" was introduced by Johann

Received September 04, 2019/Accepted October 21, 2019

Corresponding author: Marina Malobabić

Neurology Clinic, Clinical Center Niš, Dr Zoran Đinđić Boulevard 48, 18000 Nišs, Serbia

Phone: +381 18506 906•E-mail: marinasudimac@gmail.com 
Heinroth in 1818, and Felix Deutsch introduced the term "psychosomatic medicine" in 1922 (Lipsitt, 2001).

It refers to how the mind affects the body. Because this term is used to describe an individual with health complaints that do not have an obvious physical cause. In 1980, the American Psychiatric Association's (APA, 1980) Diagnostic and Statistical Manual of Mental Disorders (DSM III) replaced the existing term with "Psychological Factors Affecting Physical Conditions" in DSM-5 (Kaplan \& Sadock, 2007).

Weiner (1982), who has dealt with psychosomatic medicine, states that it deals with the influence and meaning of the disease and the psychological and social factors that play a role in the predisposition, initiation, and maintenance of the disease (Wolman, 1988). Later research by Harold Volff and his colleagues focused on the physiological effects of the experimental stress situation. These studies have developed the theory that psychosomatic disease is a response to life stress, and this way of looking at the construct has encouraged further attempts to link aspects of the physical environment and stressors to the onset and course of the disease (Moos \& Schaefer, 1984).

Psychosomatic disorders occur as a consequence of physical imbalance in which emotional components have a strong influence (Patil \& Savalagi, 2015). The link between stress and impaired health can be monitored, in such cases, as the disease appears, develops, or recurs. Psychosomatic disorders have been attributed to inadequate activation of the autonomic nervous system, endocrine and immune systems (Chinawa, Nwokocha, Manyike, Chinawa, Aniwada, \& Ndukuba, 2016). Most commonly reported symptomatology in the literature has physical, emotional, and behavioral association. The most common physical ones are muscle tension, headache (Pikó, Barabás, \& Boda, 1997), insomnia, loss of appetite, and decreased libido. Behavioral symptoms include procrastination, difficulty in fulfilling work resposibilities, changes in the amount of food, alcohol and smoking consumption, bruxism, increased or decreased desire for socialization, ruminations. Emotional symptoms include nervousness, crying, overwhelming feelings of tension or pressure, difficulty in relaxation, depression (Bilić, 2009), tendency to react violently, attention and memory disorders, ambivalence.

Alexander (1951), one of the founders of psychosomatic medicine, suggested that the term "vegetative neurosis" should be used for these types of complaints. Fenichel (1945), a prominent psychoanalyst, called the phenomenon "the influence of equivalents." These symptoms are usually found in systems that are not under the voluntary control of the nervous system, for example, diarrhea, sweating and palpitations, and are therefore part of the activity of the autonomic nervous system (Charis, 2018). Chinawa and coworkers examined the association of psychosomatic disorders with poor school performance in medical students and obtained a significant association (Chinawa et al., 2016). Most studies to date have shown that children and adolescents who use active coping strategies to reduce the discomfort caused by a stressful event experience significantly fewer psychosomatic symptoms compared to children who passively accept the situation (Vulić-Prtorić \& Cifrek-Kolarić, 2011).

Most psychosomatic symptoms are due to repression as a defense mechanism. Unlike conversion, there is no desire, fantasy, something that is socially unacceptable and causes these symptoms. Psychosomatic symptoms are simply associated with emotions (Fenichel, 1945). A patient who has unconscious conflict suppresses their emotions and develops psychosomatic symptoms due to their inability to describe emotions (Charis, 2018). The results of a very large investigation in Finland showed a significant increase in the number of psychosomatic symptoms (Santalahti, Aromaa, Sourander, Helenius, \& Piha, 2005). The 
authors suggested that some of the reasons for this could be an increased number of stressful life events (especially in the case of somatic symptoms such as headaches, abdominal pain, nausea, fatigue, etc.), changes in the family system and lifestyle during adolescence. Some somatic symptoms have been documented to be associated with leisure activities: sitting in front of a computer and playing games is a risk factor for the development of headache and back pain (Vulić-Prtorić, 2016).

\subsection{Procrastination}

The term "procrastination" is derived from the Latin term procrastinatio meaning deferral, delay, that is, from the combination of the words "pro" and "crastinus", which means "for tomorrow". Procrastination is a form of unsuccessful self-regulation, where a person "voluntarily delays the planned course of action, although he expects it to be worse due to delay" (Steel, 2007). Steel explains this phenomenon as delaying the initiation or completion of planned behavior or delaying a decision. It is characterized by avoiding a conscious and important task that is considered unpleasant, challenging or repulsive (Blunt \& Pychyl, 2000; Sirois \& Pychyl, 2013). Partnoy (2012) states that there is still debate as to whether procrastination can be an adaptive work strategy, with the suggestion that delay may be in our best interest (Fischer, 2001). Many people admit to delaying their obligations, at least to some extent. However, it happens that people postpone important obligations related to health, acquisition and general well-being. From a medical point of view, a major problem is, for example, delaying a visit to a doctor to such an extent that the disease worsens and that treatment no longer exists as an option (Saposnik, 2009; Worthlei, Cole, Esterman, Mehaffey, Roosa, Smith, et al., 2006; Steel, \& Ferrari, 2013). Van Erde (Eerde, 2003) states that all humans occasionally procrastinate. There are several divisions concerning the areas where procrastination occurs. Klingsiek (2013) states that procrastination can occur at school, at work, in daily activities, obligations, leisure, family, and partnership, as well as in social contacts. It is most common in education and business life, due to external and specific deadlines for completing a task or job. Most researchers have conceptualized procrastination as a kind of combination of three components, namely fear of failure, aversion to the task at hand, and laziness (Blunt \& Pychyl, 2000; Ferrari \& Tice, 2000; Wolters, 2003). Some students seem accustomed to delaying their work and (Kliener, 2008) about 20\% of all students postpone their work routinely to the point that it becomes a habit. Likewise, Goode (2008) suggested that longer working hours, a lot of free time and outside academic activities contribute to procrastination. Students appear to hold the perception of their self-worth by procrastination (Owens \& Newbegin, 1997; Schraw, Wadkins, \& Olfason, 2007; Hussain, \& Sultan, 2010). Research has shown that delay as a trait is associated with several acute stressrelated health problems such as headache, digestive problems, colds and flu, insomnia (Sirois, 2007; Sirois, Melia-Gordon, \& Pychyl, 2003; Sirois, Voth, \& Pychyl, 2009). Some research shows that delay can be stable over a ten year period when measured as a trait, which supports the idea that delay can also be viewed as a stable personality trait (Steel, 2007). Sirois and colleagues $(2007 ; 2003)$ state that delay can contribute to poor health outcomes through the direct impact of stress and the indirect influence of behavior. Whether we are talking about chronic delay or postponement as a personality trait, it can certainly be a source of chronic stress, with both short- and long-term health effects. Also procrastination may be associated with poor general health self-assessment (Sirois, \& Tosti, 2012), a reliable indicator and predictor of poor objective health outcomes such as cortisol responses to stress, morbidity and 
mortality (Jylhä, 2009; Kristenson, Olsson, \& Kucinskiene, 2005; Mora, Orsak, DiBonaventura, \& Leventhal, 2013; Tamayo-Fonseca, Quesada, Nolasco, Melchor, PereyraZamora et al., 2013; Sirois, \& Pychyl, 2016).

\section{METHOD}

The research was conducted among students at the Faculty of Sport and Physical Education in Niš. The sample included 424 subjects, of which 317 were male and 107 were female. Respondents ranged in age from 19 to 26 years. The study excluded 25 subjects suffering from chronic diseases (asthma, allergies, diabetes, etc.). The sample was collected over 9 months, from September 2018 to May 2019.

Psychosomatic Symptoms Scale (PSS) (Vulić-Prtorić, 2005, 2016) was used to assess perceived burden of somatic symptoms. PSS is a self-report questionnaire used to assess frequencies and perceived burden of somatic symptoms commonly seen in primary care and relevant for a large number of diseases and mental disorders. It is a 35-item scale that inquires about 35 somatic symptoms and sensations from 5 clusters: Pain-Musculoskeletal, Pseudoneurological, Gastrointestinal, Cardiovascular-Respiratory and Dermatological. The subjects scored each symptom for frequency (How often have you had these problems in the last 3 months?) as 1 (never), 2 (a few times a month), 3 (a few times a week), 4 (almost every day) and then for the degree to which each symptom interferes with their daily activities (distress) (How much does it bother you in daily activities?) as 1 (does not bother me at all), 2 (it bothers me a little) and 3 (it bothers me a lot). Reliability on our sample, for subscale of frequency is .953 , for the "How much does it bother you in daily activities?" subscale Cronbach alpha is .978. and the reliability for the scale Cronbach alpha is .976 and another instrument je Procrastination Assessment Scale (PASS) Solomon \& Rothblum, 1984. This scale is the most frequently used for measuring the academic procrastination. It contains six academic tasks (a. Writing a term paper, b. Studying for exams, c. Keeping up with weekly reading assignments, d. Academic administrative tasks, e. Attendance tasks, f. School activities in general) and each is assessed according to following sub-questions: 1 . To what extent are you delaying the execution of these tasks?; 2 . To what extent does execution of this task represent a problem for you?; 3. To what extent would you like to lessen the tendencies of delaying this activity?; That makes a total of 18 items to which the participants answer with the help of Likert five-level scale (a-never; b-almost never, c-sometimes, d-almost always, ealways). Reliability on our sample, for Procrastination scale, was confirmed by Cronbach alpha $(\alpha=.932)$.

\section{RESULTS}

There was a statistically significant difference between the male and female subsample of subjects in the frequency of occurrence of Pseudoneurological-PN ( $p=003)$, Gastrointestinal-GI ( $\mathrm{p}=032)$, Pain-Musculoskeletal-PM $(\mathrm{p}=000)$ and CardiovascularRespiratory-CR ( $p=003$ ) symptoms (Table 2$)$. The tendency to show symptoms from these groups is more common in women (Table 1). 
Table 1 Frequency of occurrence of the symptoms

\begin{tabular}{llcc}
\hline & Gender & $\mathrm{N}$ & Mean Rank \\
\hline PN & Male & 317 & 202.96 \\
& Female & 107 & 240.76 \\
& Total & 424 & \\
\hline GI & Male & 317 & 205.22 \\
& Female & 107 & 234.06 \\
& Total & 424 & \\
\hline D & Male & 317 & 211.73 \\
& Female & 107 & 214.79 \\
& Total & 424 & \\
\hline CR & Male & 317 & 202.31 \\
& Female & 107 & 242.68 \\
& Total & 424 & \\
\hline PM & Male & 317 & 199.27 \\
& Female & 107 & 251.69 \\
& Total & 424 & \\
\hline & & &
\end{tabular}

Table 2 Differences in occurrence of the psychosomatic symptoms regarding to gender

\begin{tabular}{lccccc}
\hline & PN & GI & D & CR & PM \\
\hline Mann-Whitney U & 13730.500 & 12766.000 & 13935.500 & 14652.500 & 16714.500 \\
Z & -3.012 & -3.843 & -2.931 & -2.141 & -.241 \\
Sig. & $\mathbf{. 0 0 3}$ & $\mathbf{. 0 0 0}$ & $\mathbf{. 0 0 3}$ & $\mathbf{. 0 3 2}$ & .810 \\
\hline
\end{tabular}

Grouping Variable: GENDER

There is a statistically significant positive correlation between age and the incidence of Pseudoneurological symptoms $(\rho=0.120, p=0.014)$ (Table 3 ).

Table 3 Correlation between age and the incidence of psychosomatic symptoms

\begin{tabular}{lllcccc}
\hline & & PN & GI & D & CR & PM \\
\hline \multirow{4}{*}{ Age } & Spearman & $.120^{*}$ & .031 & -.008 & .066 & .077 \\
& Sig & .014 & .519 & .862 & .174 & .115 \\
& $\mathrm{~N}$ & 424 & 424 & 424 & 424 & 424 \\
\hline \multicolumn{5}{r}{ *. Correlation is significant at the 0.05 level (2-tailed). }
\end{tabular}

There was no statistically significant difference $(\chi 2=0.385 ; \mathrm{df}=1 ; \mathrm{p}=0.535)$ between the male and female sub-sample in the degree of procrastination manifestation (Table 4).

Table 4 Sub-sample differences in the degree of procrastination manifestation

\begin{tabular}{cccc}
\hline Procrastination & & & \\
& Value & Degrees of freedom & Sig. (2-sided) \\
\hline Pearson Chi-Square & .385 & 1 & .535 \\
\hline
\end{tabular}

There was a statistically significant positive low correlation between age and procrastination quotient $(\rho=0.103 ; p=0.034)$ (Table 5). 
Table 5 Correlation between age and procrastination quotient

\begin{tabular}{ccc}
\hline & & Procrastination \\
\hline Age & Spearman & $.103^{*}$ \\
& Sig & $\mathbf{. 0 3 4}$ \\
& $\mathrm{N}$ & 424 \\
\hline
\end{tabular}

There was a positive low correlation between the tendency to exhibit Pseudoneurological $(\rho=0.112 ; p=0.021)$, Gastrointestinal $(\rho=0.131 ; p=0.007)$, Cardiovascular-Respiratory $(\rho$ $=0.114 ; \mathrm{p}=0.019)$, and Pain-Musculoskeletal symptoms $(\rho=0.098 ; \mathrm{p}=0.044)$ and Procrastination (Table 6).

Table 6 Correlation between the tendency to exhibit psychosomatic symptoms and procrastination

\begin{tabular}{rcccccc}
\hline & & PN & GI & D & CR & PM \\
\hline \multirow{4}{*}{ Procrastination } & Spearman & $.112^{*}$ & $.131^{* *}$ & .080 & $.114^{*}$ & $.098^{*}$ \\
& $\mathrm{Sig}$ & $\mathbf{. 0 2 1}$ & $\mathbf{. 0 0 7}$ & .099 & $\mathbf{. 0 1 9}$ & $\mathbf{. 0 4 4}$ \\
& $\mathrm{N}$ & 424 & 424 & 424 & 424 & 424 \\
\hline \\
*. Correlation is significant at the 0.01 level (2-tailed). \\
*. Correlation is significant at the 0.05 level (2-tailed).
\end{tabular}

\section{DISCUSSION}

The aim of this study was to investigate the association between the tendency to manifest psychosomatic reactions and procrastination in students of the Faculty of Sport and Physical Education, as well as to examine the differences in the tendency to manifest psychosomatic symptoms and procrastination concerning gender and age.

There was a difference in the tendency to exhibit Pseudoneurological, CardiovascularRespiratory and Gastrointestinal symptoms, as well as Pain-Musculoskeletal symptoms. Women are more likely to report these symptoms. Such findings are in line with findings in research in developmental psychopathology, which showed that girls are generally more anxious than boys (Vulić-Prtorić and Cifrek-Kolarić, 2011). In a study conducted by Reich (1986) and later by Kashani \& Orvaschel (1990), women were found to report the presence of more anxiety symptoms and disorders than men. The assumption is that girls are more anxious in the sense that there are multiple situations to which they respond with anxiety symptoms. Other interpretations emphasize the diversity of expression of anxiety caused by cultural factors (Ndetei and Vadher, 1984) and the influence of upbringing through which different attitudes of boys and girls toward accepting and acknowledging anxiety (VulićPrtorić and Cifrek-Kolarić, 2011) are built.

A study conducted by Vulić-Prtorić and Cifrek-Kolarić on a sample of 1309 subjects found that girls of all ages had higher scores than boys. In relation to boys, girls estimate that the symptoms they experience generally hinder them significantly in their daily life.

In studies of the association between age and anxiety, according to one hypothesis, the level of anxiety rises as a function of age, and according to the other, anxiety at different periods remains relatively the same, but the contents of fear changes as the child gets older. In most studies, it has been shown that the number of symptoms has increased with age, but qualitative changes have also been observed, ie, some, at first, rare symptoms, some 
conversion symptoms (visual impairment, hearing, chronic fatigue...) (Loge, Ekeberg, \& Kaasa, 1998). Some studies have shown that older respondents score higher on anxiety tests (Akande, 1990; Hodge, McCormick, \& Elliott, 1997; Mousavi, Haghshenas, \& Alishahi, 2008). Our results are consistent with these results because we have shown that in our sample the tendency to exhibit pseudoneurological symptoms increases with age.

The studies conducted so far mainly indicate that there are differences in procrastination between men and women. Studies conducted by Gröpel and Steel (2008) and Steel (2007) showed that men have higher levels of impulsivity (Strüber, Lück \& Roth, 2008) and lower levels of self-control (Higgins \& Tewksbury, 2006), which are key determinants of procrastination. Contrary to expectations, Owens \& Newbegin (2000) stated that there were no significant differences between male and female subjects in the severity of procrastination. Our results also showed that there were no statistically significant differences in the tendency to procrastinate between male and female subjects.

The association between age and tendency to procrastination has also been established. As we mature, we become more conscientious (Roberts, Walton, \& Viechtbauer, 2006), a trait that is strongly associated with procrastination (Steel \& Ferrrari, 2013). In the study, we obtained results consistent with expectation - there is a correlation between age and procrastination.

Numerous studies have suggested an association between anxiety and academic procrastination (Lay, 1995; Onwuegbuzie 2004) have been fertile ground for hypothesizing that there will be a statistically significant association between the tendency to exhibit psychosomatic symptoms and procrastination. Various researchers have found primary and secondary problems associated with academic procrastination, such as low levels of student achievement and increased levels of their physical and psychological problems (Ferrari \& Pychyl, 2008), irresponsibility and irregularity (Rivait 2007) (Hussain \& Sultanm, 2010). However, Essau and colleagues (Essau, Ederer, O'Callaghan, \& Aschemann, 2008) concluded that, in fact, a high level of procrastination prevents students from organizing themselves in pursuing academic goals which further causes depression, anxiety, and stress. Persistence and regularity of procrastination can become a way of behavior, especially for students. When procrastination becomes extreme, people also postpone important commitments related to health, finances, and well-being. The biggest problem arises in the domain of health, as people delay the visit to the doctor because of their problems, leaving them room to develop to such an extent when cure is not possible (e.g. Saposnik, 2009; Worthley et al., 2006). Steel and Ferrari (2013) examined the association between procrastination and health, work and education, but it is evident that procrastination has a significant impact on all domains of life.

Schourwenburg and colleagues (Schourwenburg, Lay, Pychyl, \& Ferrari, 2004) found that over $70 \%$ of North American students procrastinate. Increasing research indicates that procrastination is common among students (Hill, Hill, Chabot, \& Barrall, 1978; McCown, Johnson, \& Petzel, 1989), and that students with a greater tendency to procrastinate are particularly vulnerable to adjustment problems (Flett, Blankstein, \& Martin, 1995; Lay, 1995; Rothblum, Solomon, \& Murakami, 1986; Solomon \& Rothblum, 1984) (Hewitt \& Flett, 1993). As the results have already shown, this can grow into a pattern of behavior as a person matures. The level of procrastination in studies ranges from $46 \%$ (Solomon \& Rothblum, 1984) to $95 \%$ (Ellis \& Knaus, 1977).

Our findings where a correlation between procrastination and a tendency to exhibit pseudoneurological problems was found can be explained by the fact that distress is the best example of the association between psychiatric and physical problems. These symptoms can 
be exacerbated by emotions, and include one or more ANS-controlled (autonomic nervous system) organ systems. Children and adolescents who tend to respond psychosomatically to their fears and tensions express somatic problems (Vulić-Prtorić, 2005). In situations where a person is dealing with a situation, psychosomatic symptoms can become uncomfortable and interfere with daily functioning, including performing academic obligations (Gugić, 2015) and may also occur as a way of relieving emotional tension when more appropriate symbolic expression cannot be found. Tension can cause anxiety and anticipation of possible danger. Anxiety is a universal experience associated with many physiological reactions such as high blood pressure, suffocation, and hyperventilation, tremor, nausea, headache, insomnia, dizziness... (Vulić-Prtorić \& Cifrek-Kolarić, 2011).

Delaying responsibilities can make a person anxious. When people are faced with a difficult task, and even when its execution is delayed, anxiety rises. Even from the very thought of the task, tension grows. Anxiety, on the other hand, prevents them from concentrating on the task, so that then the anxiety grows even more (Bachrach, 2012).

\section{CONCLUSIONS}

The results of this study show that there is a significant positive correlation between the tendency to exhibit pseudoneurological, gastrointestinal, cardiovascular-respiratory and pain-musculoskeletal symptoms and procrastination. These findings are consistent with many previous studies that have shown an association between anxiety, neuroticism, psychological distress, and academic procrastination. There was also a statistically significant positive correlation between age and frequency of pseudoneurological symptoms, as well as between age and procrastination rate. We also found that women were more likely to exhibit psychosomatic problems, which is consistent with findings from developmental psychopathology that show that girls are generally more anxious than boys.

\section{REFERENCES}

Adamović, V. (1983). Emocije i telesne bolesti. Beograd: Nolit.

Akande A. (1990). Influence of urban-rural upbringing on Nigerian students' test anxiety. Psychological Reports 67(3), 1261-1262.

Alexander, F. (1951). Psychosomatische Medizin. Berlin: De Gruyter.

American Psychiatric Association. (1980). Diagnostic and statistical manual of mental disorders ( $3^{\text {rd }}$ ed., Text Revisicon). Washington, DC: Author.

APA. (2010) American Psychological Association: Psychology of Procrastination: Why People Put Off Important Tasks Until the Last Minute. Washington DC: Author.

Bachrach, A. (2012) Understanding the Pscyhology of Procrastination and Overcoming it [online]. Available on: http://www.mosaichub.com/resource_center/resource/understanding-the-psychology-of-procrastination [15. 6. 2014].

Bilić, V. (2009). Psihološki čimbenici kod kardiovaskularnih bolesti. Medix, 83(15), 100-103.

Blunt, A., \& Pychyl, T. (2000). Task aversiveness and procrastination: A multi-dimensional approach to task aversiveness across stages of personal projects. Personality and Individual Differences, 28(1), 153-167.

Charis, C. (2018). Somatoform Disorders from Psychodynamic Point of View. In Somatoform and Other Psychosomatic Disorders 23-38. Springer, Cham.

Chinawa, J. M., Nwokocha, A. R., Manyike, P. C., Chinawa, A. T., Aniwada, E. C., \& Ndukuba, A. C. (2016). Psychosomatic problems among medical students: a myth or reality?. International journal of mental health systems, 10(1), 72 .

Ellis, A. \& Knaus, W. (1977). Overcoming Procrastination. Institute Of Rational Living: New York. 
Essau, C.A., Ederer, E.M., O’Callaghan, J., \& Aschemann, B. (2008). Doing it now or later? Correlates, predictors and prevention of academic, decisional and general procrastination among students in Austria. A Poster Presentation at the Presentation at the 8th Alps-Adria Psychology Conference, October 2-4, Ljubljana, Slovenia.

Fenichel, O. (1945). The psychoanalytic theory of neurosis. London: Routledge

Ferrari, J., \& Pychyl, T. (2008). Procrastination: Current Issues and New Directions, Volume 15(5).

Ferrari, J., \& Tice, D. (2000). Procrastination as a self-handicap for men and women: A task-avoidance strategy in a laboratory setting. Journal of Research in Personality, 34, 73-83.

Fischer, C. (2001). Read this paper later: Procrastination with time-consistent preferences. Journal of Economic Behavior \& Organization, 46, 249-269.

Flett, G. L., Blankstein, K. R., \& Martin, T. R. (1995). Procrastination, negative self-judgments, andstress in depression and anxiety: A review and preliminary model. In J. Ferrari, J. Johnson, \&W. McCown (Eds.), Procrastination and task avoidance: Theory, research, and treatment (pp.137-167). New York: Plenum.

Goode, C. (2008). Effects Of Academic Procrastination: Students Procrastination Affects More Than Grades. Retrieved from website http://homeworktree.com/media/news-releases/academic-procrastination accessed on October 13, 2008.

Gröpel, P., \& Steel, P. (2008). A mega-trial investigation of goal setting, interest enhancement, and energy on procrastination. Personality and Individual Differences, 45(5), 406-411.

Gugić, K. (2015). Suočavanje sa stresom, anksioznost i psihosomatski simptomi kod adolescenata. Doctoral dissertation. Osijek: Univerzitet Josipa Jurja Strossmayera.

Hasanagić, A., \& Ogulmus, C. B. (2015). Procrastination and Anxiety of Students of Private and State University in $\mathrm{BiH}$. Zbornik radova Islamskog pedagoškog fakulteta u Zenici 12, 57-75.

Hewitt, P. L., \& Flett, G. L. (1993). Dimensions of perfectionism, daily stress, and depression: a test of the specific vulnerability hypothesis. Journal of abnormal psychology, 102(1), 58.

Higgins, G. E., \& Tewksbury, R. (2006). Sex and Self-Control Theory: The measures and causal model may be different. Youth Society, 37(4), 479-503.

Hill, M., Hill, D., Chabot, A., \& Barrall, J. (1978). A survey of college faculty and student procras-tination. College Student Personnel Journal, 12, 256-262.

Hodge GM, McCormick J, Elliott R. (1997). Examination-induced distress in a public examination at the completion of secondary schooling. Br J Educational Psychology 67, 185-97.

Hussain, I., \& Sultan, S. (2010). Analysis of procrastination among university students. Procedia-Social and Behavioral Sciences, 5, 1897-1904.

Jylhä, M. (2009). What is self-rated health and why does it predict mortality? Towards a unified conceptual model. Social Science \& Medicine, 69(3), 307-316.

Kaplan, J., \& Sadock, M. D. (2007). Comprehensive Textbook of Psychiatry 10th ed. Vol. I/II. USA: Williams \& Wilkins.

Kashani, J. H., \& Orvaschel, H. (1990). A community study of anxiety in children and adolescents. The American journal of psychiatry, 147(3), 313-8.

Kliener, K. (2009). When Manama Is Too Soon. Retrieved from www.thestar.com accessed on December 21, 2009.

Klingsieck, K. B. (2013). Procrastination in different life-domains: is procrastination domain specific?. Current Psychology, 32(2), 175-185.

Kristenson, M., Olsson, A., \& Kucinskiene, Z. (2005). Good self-rated health is related to psychosocial resources and a strong cortisol response to acute stress: the LiVicordia study of middle-aged men. International Journal of Behavioral Medicine, 12(3), 153-160.

Lay, C. H. (1995). Trait procrastination, agitation, dejection, and self-discrepancy. In J. Ferrari, J.Johnson, \& W. McCown (Eds.), Procrastination and task avoidance: Theory, research, and treatment (pp. 97-112). New York: Plenum

Levenson, J. L. (Ed.). (2011). Textbook of psychosomatic medicine: Psychiatric care of the medically ill. APPI.

Lipsitt, D.R., (2001). Consultation-liaison psychiatry and psychosomatic medicine: the company they keep. Psychosomatic Medicine 63, 896-909.

Loge, J. H., Ekeberg, Ø., \& Kaasa, S. (1998). Fatigue in the general Norwegian population: normative data and associations. Journal of psychosomatic research, 45(1), 53-65.

López, R., Calabuig, J., \& Barber, X. (2013). Self-rated health and mortality: a follow-up study of a Spanish population. Public Health, 127(12), 1097-1104.

McCown, W., Johnson, J., \& Petzel, T. (1989). Procrastination, a principal components analysis. Personality and Individual Differences, 10, 197-202.

Moos, R. H., \& Schaefer, J. A. (1984). The crisis of physical illness. In Coping with physical illness (pp. 3-25). Springer, Boston, MA. 
Mora, P. A., Orsak, G., DiBonaventura, M. D., \& Leventhal, E. A. (2013). Why do comparative assessments predict health? The role of self-assessed health in the formation of comparative health judgments. Health Psychology, 32(11), 1175-1178.

Mousavi, M., Haghshenas, H., \& Alishahi, M. J. (2008). Effect of gender, school performance and school type on test anxiety among Iranian adolescents. Iranian red crescent medical journal 10(1), 4-7.

Ndetei, D. M., and Vadher, A. (1984). Pattern of Anxiety in a Cross-Cultural Hospital Population. Acta Psychiatrica Scandinavia, 70, 69-72

Onwuegbuzie, A. (2004). Academic Procrastination And Statistics Anxiety. Assessment And Evaluation In Higher Education, 29(1), 3-19.

Owens, A. M., \& Newbegin, I. (1997). Procrastination in high school achievement: A causal structural model. Journal of Social Behavior and Personality, 12(4), 869.

Owens, A. M., \& Newbegin, I. (2000). Academic procrastination of adolescents in english and mathematics: gender and personality variations. Journal of Social Behavior and Personality, 15(5), 111

Owens,A. \& Newbegin, I. (1997). Procrastination In High School Achievement: A Causal Structural Model. Journal Of Social Behaviour And Personality, 3, 201-214.

Partnoy, F. (2012). Wait: The art and science of delay. New York: Public Affairs.

Patil, P. B., \& Savalagi, A. G., (2015) Psychosomatic disorders of the oral cavity- a review. American Journal of Oral Medicine and Radiology 2(2), 96-102.

Pikó, B., Barabás, K., \& Boda, K. (1997). Frequency of common psychosomatic symptoms and its influence on self-perceived health in a Hungarian student population. The European Journal of Public Health, 7(3), 243-247.

Reich, J. (1986). The epidemiology of anxiety. Journal Nerv Ment Dis 174, 129-136.

Rivait, L. (2007). What I Don't Do In My Summer Vacations: Fighting Procrastination. Retrieved from http://www.past the pages.ca/feature.htm accessed on December 21, 2009.

Roberts, B. W., Walton, K. E., \& Viechtbauer, W. (2006). Patterns of mean-level change in personality traits across the course: A metaanalysis of longitudinal Studies. Psychological Bulletin 132, 1-25.

Rothblum, E., Solomon, L., \& Murakami, J. (1986). Affective, cognitive and behavioral differencesbetween high and low procrastinators. Journal of Counseling Psychology, 33, 387-394

Santalahti, P., Aromaa, M., Sourander, A., Helenius, H., \& Piha, J. (2005). Have there been changes in children's psychosomatic symptoms? A 10-year comparison from Finland. Pediatrics, 115, 434-442.

Saposnik, G. (2009). Acute stroke management: Avoiding procrastination, the best way to optimize care delivery. European Journal of Neurology, 16(12), 1251-1252.

Schouwenburg, H., Lay, C., Pychyl, T. \& Ferrari, J. (2004). Counseling The Procrastinator In Academic Settings, Washington D.C.: American Psychological Association.

Schraw, G., Wadkins, T., \& Olafson, L. (2007). Doing the things we do: A grounded theory of academic procrastination. Journal of Educational psychology, 99(1), 12.

Sirois, F. M. (2007a). "I'll look after my health, later": A replication and extension of the procrastinationhealth model with community-dwelling adults. Personality and Individual Differences, 43, 15-26.

Sirois, F. M., \& Pychyl, T. (2013). Procrastination and the priority of short-term mood regulation: Consequences for future self. Social and Personality Psychology Compass, 7(2), 115-127.

Sirois, F. M., \& Pychyl, T. A. (2016). Future of research on procrastination, health, and well-being: Key themes and recommendations. In Procrastination, health, and well-being (pp. 255-271). Academic Press.

Sirois, F. M., \& Tosti, N. (2012). Lost in the moment? An investigation of procrastination, mindfulness, and well-being. Journal of Rational-Emotive \& Cognitive-Behavior Therapy, 30(4), 237-248.

Sirois, F. M., Melia-Gordon, M. L., \& Pychyl, T. A. (2003). "I'll look after my health, later": An investigation of procrastination and health. Personality and Individual Differences, 35(5), 1167-1184

Sirois, F. M., Voth, J., \& Pychyl, T. A. (2009). "I'll look after my health, later": A prospective study of the linkages of procrastination to health and well-being in undergraduate students. Paper presented at the 6th Biennial conference of Counselling the Procrastinator in Academic Settings, York University, Toronto, ON.

Solomon, L., \& Rothblum, E. (1984). Academic procrastination: Frequency and cognitive-behavioral correlates. Journal of Counseling Psychology, 31, 503-509.

Steel, P. (2007). The nature of procrastination: A meta-analytic and theoretical review of quintessential selfregulatory failure. Psychological Bulletin, 133(1), 65-94.

Steel, P., \& Ferrari, J. (2013). Sex, education and procrastination: an epidemiological study of procrastinators' characteristics from a global sample. European Journal of Personality, 27(1), 51-58.

Strüber, D., Lück, M., \& Roth, G. (2008). Sex, aggression and impulse control: an integrative account. Neurocase, 14(1), 93-121.

Tamayo-Fonseca, N., Quesada, J. A., Nolasco, A., Melchor, I., Moncho, J., Pereyra-Zamora, P., López R, Calabuig J, Barber X. (2013). Self-rated health and mortality: a follow-up study of a Spanish population. Public health 127(12), 1097-104. 
Van Eerde, W. (2003). A meta-analytically derived nomological network of procrastination. Personality and individual differences, 35(6), 1401-1418

Vulić-Prtorić, A. (2005). Upitnik psihosomatskih simptoma za djecu i adolescente. Suvremena psihologija, 8(2), 211-227.

Vulić-Prtorić, A. (2016). Somatic complaints in adolescence: Prevalence patterns across gender and age. Psihologijske teme, 25(1), 75-105.)

Vulić-Prtorić, A. i Cifrek-Kolarić M. (2011). Istraživanja u razvojnoj psihopatologiji. Jastrebarsko: Naklada Slap.

Weiner, H. Contemporary research and the mind-body problem. In R. W. Rieber (Ed.), Body and mind (pp. 223-240). New York: Academic Press, 1980.

Weiner, H. Psychological factors in bodily disease. In T. Millon, C. Green, \& R. Meagher (Eds.), Handbook of clinical health psychology (pp. 31-52). New York: Plenum Press, 1982.

Weiner, H., Hofer, M., \& Stunkard, A.J., (Eds.). Brain, behavior and bodily disease. New York: Raven Press, 1980.

Wolman, B.B. (1998). Psychosomatic Disorders. New York: Plenum Medical Book Company 1988

Wolters, C.A. (2003). Understanding procrastination from a selfregulated learning perspective. Journal of Educational Psychology, 95, 179-187

Worthley, D.L., Cole, S. R., Esterman, A., Mehaffey, S., Roosa, N. M., Smith, A.,...Young, G. P. (2006). Screening for colorectal cancer by faecal occult blood test: Why people choose to refuse. Internal Medicine Journal, 36(9), 607-610.

Zotović, M. (2002). Stres i posledice stresa: prikaz transakcionističkog teorijskog modela. Psihologija, 35(1-2), 3-23.

\section{IZRAŽENOST PSIHOSOMATSKIH TEGOBA I PROKRASTINACIJE KOD STUDENATA}

Cilj istraživanja bio je ispitati povezanosti između tendencije ka ispoljavanju psihosomatskih reakcija i prokrastinacije kod studenata Fakulteta sporta i fizičkog vaspitanja kao i ispitivanje razlika u tendenciji ka ispoljavanju psihosomatskih simptoma i prokrastinacije u odnosu na pol $i$ godine starosti. U istraživanju je učestvovalo 459 studenata Fakulteta sporta i fizičkog vaspitanja u Nišu, od kojih je iz ispitivanja isključeno 25 ispitanika koji boluju od hroničnih bolesti (astma, alergije, dijabetes itd). Ispitanici su ispunjavali upitnike Psychosomatic Symptoms Scale (PSS) (Vulić-Prtorić, 2005, 2016) i Procrastination Assessment Scale (PASS) (Solomon \& Rothblum, 1984). Rezultati ovog istraživanja su pokazali da postoji značajna pozitivna korelacija između tendencije ka ispoljavanju pseudoneuroloških, kardiorespiratornih, gastrointestinalnih i muskulatornih simptoma (uz osećaj bola i slabosti) i prokrastinacije, statistički značajna pozitivna korelacija između godina starosti $i$ frekvencije javljanja pseudoneuroloških simptoma, kao i statistički značajna korelacija između godina starosti i koeficijenta prokrastinacije. Takođe smo utvrdili i da žene češće pokazuju tendenciju ka ispoljavanju psihosomatskih tegoba od muškaraca.

Ključne reči: psihosomatski simptomi, pseudoneurološki simptomi, prokrastinacija. 